\title{
Carboxypeptidase $\mathrm{H}$ in the Hypothalamo-Neurohypophysial System: Evidence for Processing and Activation of a Prohormone-Processing Enzyme During Axonal Transport
}

\author{
Vivian Y. H. Hook, ${ }^{1}$ Hans-Urs Affolter, ${ }^{2}$ and Miklos Palkovits ${ }^{3}$ \\ 'Department of Biochemistry, Uniformed Services University of the Health Sciences, Bethesda, Maryland 20814, 2Institute \\ for Brain Research, University of Zurich, Switzerland, and ${ }^{3}$ Department of Anatomy, Semmelweis University Medical \\ School, Budapest, Hungary and Laboratory of Cell Biology, National Institute of Mental Health, Bethesda, Maryland 20892
}

Investigations of peptide precursor processing in nerve cells, including studies on prooxytocin and provasopressin processing in the rat hypothalamo-neurohypophysial system, show that prohormone processing occurs during axonal transport of maturing secretory vesicles. Recent studies (Fricker et al., 1989; Rodriguez et al., 1989) show that carboxypeptidase $\mathrm{H}$ (CPH), one of several proteases required for prohormone processing, is synthesized as a proenzyme that presumably requires activation. To determine if pro$\mathrm{CPH}$, like prohormone precursors, is processed and activated during axonal transport, we have analyzed the molecular forms of CPH present at several levels in the rat hypothalamo-neurohypophysial system. These biochemical and immunochemical studies showed that the supraoptic nucleus (SON), a region enriched in neuronal cell bodies, possesses primarily an inactive 65-kDa species of $\mathrm{CPH}$. The median eminence and pituitary stalk regions that are enriched in axons possess both the inactive 65-kDa and the active 55-kDa forms of CPH, and nerve terminals of the posterior pituitary contain primarily the active 55-kDa CPH. These results support the hypothesis that pro-CPH is processed and activated during axonal transport from neuronal perikarya of SON to nerve terminals of the posterior pituitary. Furthermore, analysis of immunoreactive $\mathrm{CPH}$ in the rat and bovine pituitary showed that each tissue possessed different relative amounts of zymogen compared to mature forms of $\mathrm{CPH}$, suggesting that tissue-specific processing of proCPH occurs. Thus, the biosynthesis of active peptide hormones requires the simultaneous processing of proenzyme and prohormone.

It is well known that numerous peptide hormones and neurotransmitters are synthesized as prohormone precursors that must undergo limited proteolysis to yield the smaller, physiologically active peptides. Carboxypeptidase $\mathrm{H}(\mathrm{CPH})(\mathrm{Webb}, 1986)$ is one of the later processing enzymes in the proteolytic cascade

\footnotetext{
Received Aug. 24, 1989; revised April 20, 1990; accepted May 4, 1990.

We thank Dr. F. J. Bollum and Dr. T. J. Krieger for helpful comments on this manuscript. This work was supported by a grant to V.H. from the National Institute of Drug Abuse. The opinions or assertions contained herein are the private ones of the authors and are not to be construed as official or reflecting the views of the Department of Defense or the Uniformed Services University of the Health Sciences.

Correspondence should be addressed to Dr. Vivian Hook at the above address. Copyright (c) 1990 Society for Neuroscience 0270-6474/90/103219-08\$03.00/0
}

required for conversion of prohormones such as provasopressin, prooxytocin, proenkephalin, and others into the smaller, active peptides. Subsequent to the action of trypsin-like endopeptidase(s) that cleave at pairs of dibasic amino acid residues (lysine, arginine) within the precursor (Docherty and Steiner, 1982; Gainer et al., 1985), CPH (previously referred to as "carboxypeptidase B-like" (Hook and Loh, 1984; Hook et al., 1985b), "enkephalin convertase" (Fricker and Snyder, 1982, 1983), and "carboxypeptidase E" (Fricker et al., 1989)l removes the COOHterminal lysine and/or arginine extensions on the peptide. Biochemical studies (Fricker and Snyder, 1982, 1983; Hook et al., 1982; Hook and Loh, 1984; Supattapone et al., 1984; Davidson and Hutton, 1987) show that CPH can be distinguished from carboxypeptidase $B$ and carboxypcptidase $N$, which also possess specificities for basic amino acid residues, by its acidic $\mathrm{pH}$ optimum, thiol dependence, potency of guanidinoethylmercaptosuccinic acid (GEMSA) inhibition, and molecular weight. Immunochemical studies (Hook et al., 1985b) showed that a specific anti-CPH antibody does not crossreact with carboxypeptidases $\mathrm{B}, \mathrm{N}, \mathrm{A}, \mathrm{Y}$, or $\mathrm{P}$, suggesting that $\mathrm{CPH}$ is a structurally distinct carboxypeptidase. Analysis of the amino acid sequence deduced from the CPH cDNA (Fricker et al., 1989; Rodriguez et al., 1989) confirms that $\mathrm{CPH}$ is a unique carboxypeptidase that is involved in the production of a variety of peptide hormones and neurotransmitters.

Earlier investigations (Hook et al., 1985a) on the regulation of $\mathrm{CPH}$ showed that catalytically inactive and active forms exist. $\mathrm{CPH}$ activity was increased without changes in cellular levels of $\mathrm{CPH}$ immunoreactivity during elevated rates of enkephalin peptide biosynthesis in primary cultures of adrenal medullary chromaffin cells. Therefore, while the total number of carboxypeptidase enzyme molecules remained constant, there may be a conversion of existing enzyme molecules to a more active form. Other studies (Hook and Eiden, 1985) show that $\mathrm{CPH}$ is more active in mature chromaffin granules containing fully processed enkephalin peptides than in a mixed population of immature and mature granules containing partially and fully processed proenkephalin. These findings indicate that $\mathrm{CPH}$ may undergo a process of activation during secretory vesicle maturation.

Recent molecular cloning of rat CPH (Fricker et al., 1989; Rodriguez et al., 1989) showed that the enzyme is initially synthesized as a precursor, prepro- $\mathrm{CPH}$, which requires processing and activation. In neurons, pro- $\mathrm{CPH}$ is presumably transported with prohormones in secretory vesicles from the neuronal peri- 


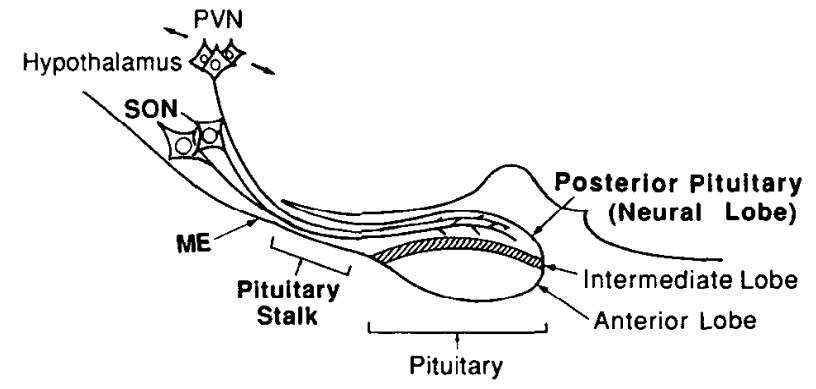

Figure 1. Rat HNS. Hypothalamic cell bodies located in the SON and PVN send axons through the ME and pituitary stalk, which terminate in the posterior pituitary (neural lobe) of the rat pituitary.

karya via axons to nerve terminals; this hypothesis, however, has not been tested. Studies of prohormone processing in the rat hypothalamo-neurohypophysial system (HNS) (Fig. 1) have shown that secretory vesicle maturation and prohormone processing take place as vesicles are axonally transported from hypothalamic cell bodies of the supraoptic nucleus (SON) and paraventricular nucleus (PVN) to nerve terminals in the posterior pituitary (Gainer et al., 1977; Brownstein et al., 1980; Liston et al., 1984). The HNS should be an excellent system to determine if an inactive form of CPH may be activated during vesicle maturation and axonal transport. Therefore, in this study, we have analyzed the molecular forms of $\mathrm{CPH}$ present at several levels in the rat HNS using a specific, well-characterized antibovine CPH antibody (Hook et al., 1985b) in conjunction with enzyme activity assays.

The $\mathrm{CPH}$ antiserum has been used in immunocytochemical studies (Hook et al., 1985b) to visualize the discrete localization of CPH in neurons of the rat SON and PVN, where it is involved in the processing of provasopressin (Hook and Loh, 1984), prooxytocin (Kanmera and Chaiken, 1985), and proenkephalin (Hook and Loh, 1984). Further resolution by electron microscopic immunohistochemistry confirmed that $\mathrm{CPH}$ in these neurons is localized to secretory vesicles in cell body, dendrite, axon, and nerve terminals (Hook et al., 1985b). This antibody recognizes CPH from the rat, monkey, and cat (Hook et al., 1985b; Chesselet and Hook, 1988) indicating that CPH from several species share some structural similarities.

In this report, analysis of zymogen and active forms of $\mathrm{CPH}$ in the rat HNS suggest that a precursor form of CPH in the SON appears to be converted during axonal transport to catalytically active $\mathrm{CPH}$, the major form of $\mathrm{CPH}$ present in nerve terminals of the posterior pituitary. These studies suggest that conversion of zymogen to the mature form of $\mathrm{CPH}$ may play a role in the control of peptide hormone biosynthesis. Furthermore, the maturation of secretory vesicles during axonal transport may include mechanisms for the activation of CPH and other prohormone-processing enzymes.

\section{Materials and Methods}

Tissue dissection. From freshly decapitated male Sprague-Dawley rats (250 gm, Zivic Miller), the median eminence (ME) and pituitary stalk were dissected together and taken as the axon region (ME-stalk). The SON was microdissected separately. The posterior pituitaries were separated from the anterior and intermediate lobes while tissues were kept moist. All tissues were dissected under an operating microscope and then immediately frozen on dry ice.

Stalk transected, sham-operated, and control (no surgery) male rats were obtained from Zivic Miller. Thirteen days after surgery, the posterior pituitaries from 6 rats in each group were removed and frozen on dry ice. Degeneration of the pituitary stalk was confirmed by microscopic examination. Posterior pituitary tissue weight after stalk transection has been shown to be reduced to $50 \%$ of sham controls (Laszlo and DeWied, 1966), and protein content in this experiment was reduced to $25 \%$ of controls.

Preparation of homogenates, and soluble and membrane fractions. After tissue dissection, ME-stalks and posterior pituitaries from 10 rats were pooled and sonicated on ice in $100 \mu \mathrm{l} 0.1 \mathrm{M} \mathrm{Na}$-acetate $(\mathrm{pH}, 5.7)$ for preparation of tissue homogenates. Soluble and membrane-associated fractions were prepared by centrifuging the homogenate in a Beckman airfuge for $10 \mathrm{~min}$ at $4^{\circ} \mathrm{C}$. The supernatant was taken as the soluble fraction, and the pellet, which was washed 2 times in homogenate buffer (100 mM Na-acetate; $\mathrm{pH}, 5.7)$, was taken as the membrane-associated fraction. The membrane-associated fraction represents proteins "associated" with the membrane and integral membrane proteins. Protein content was determined by the method of Lowry (Lowry et al., 1951) with bovine serum albumin as standard.

Homogenates from bovine pituitary were prepared by dissecting anterior, intermediate, and neural lobes from fresh pituitarics (Biological Research and Development, Gaithersburg, MD), and homogenization was in 5 vol $0.1 \mathrm{M} \mathrm{Na}$-acetate $(\mathrm{pH}, 5.7)$. Aliquots $(8-10 \mu \mathrm{g}$ protein) were subjected to $\mathrm{CPH}$ immunoblot analysis.

Carboxypeptidase Hactivity. CPH activity was measured by following the conversion of ${ }^{3} \mathrm{H}$-benzoyl-Phe-Ala-Arg (New England Nuclear) to ${ }^{3} \mathrm{H}$-benzoyl-Phe-Ala, and $\mathrm{CPH}$ activity was calculated as the difference between $\mathrm{CoCl}_{2}$-stimulated ( $3 \mathrm{~mm}$ ) and guanidinopropylsuccinic acid (GPSA)- (1.2 $\mu \mathrm{M})$ inhibited activities, as previously described (Stack et al., 1984; Hook and LaGamma, 1987). Enzyme activities were quantitated in the linear range of the assay.

Carboxypeptidase $\mathrm{H}$ immunoreactivity. CPH immunoreactivity (IR) in homogenate samples was measured by radioimmunoassay using a specific CPH antiserum (Hook et al., 1985b). Homogenates were diluted 1:2 with a triton-containing buffer [final concentrations: $100 \mathrm{~mm} \mathrm{Na}$ phosphate $(\mathrm{pH}, 7.4), 0.5$ trypsin inhibitor units $/ \mathrm{ml}$ of Trasylol (Sigma), $0.1 \%$ bovine serum albumin, $0.01 \%$ merthiolate, $0.1 \%$ Triton $\mathrm{X}-100$, and $10 \mathrm{mM}$ EDTA] to solubilize the membrane-bound enzyme. After remaining on ice for $2 \mathrm{hr}$, the solubilized samples were centrifuged for 5 min in a Beckman microfuge at $4^{\circ} \mathrm{C}$, and the supernatants were assayed for CPH IR as described previously (Hook et al., 1985b).

Immunoblots. Immunoblots were performed essentially as described previously (Hook et al., 1985b). Briefly, samples were subjected to $10 \%$ SDS-PAGE and electrophoretically transferred to nitrocellulose membranes (Schleicher and Schuell). Membranes were blocked with $10 \%$ fetal calf serum in PBS ( $\mathrm{pH}, 7.4)$ for $2 \mathrm{hr}$. They were then incubated with anti-CPH antibody at a final dilution of $1: 1000$ in PBS (pH, 7.4), washed with $0.05 \%$ NP-40/PBS 3 times, incubated with goat anti-rabbit peroxidase-conjugated secondary antibody $[10 \mu \mathrm{l}$ in $10 \mathrm{ml} 10 \%$ fetal calf serum/PBS (pH, 7.4), Boehringer Mannheim], and washed 3 times with $0.05 \%$ NP-40/PBS. The peroxidase was visualized with 4-chloro1-naphthol (Aldrich) as substrate. Selected lanes on the immunoblots were scanned with a Shimadzu laser densitometer.

p-Aminobenzoylarginine-Sepharose affinity chromatography. SON, ME-stalk, and neural-lobe tissues (20 rats for each region) were homogenized in $200 \mu \mathrm{l}$ buffer A, composed of $50 \mathrm{mM} \mathrm{Na}$-acetate $(\mathrm{pH}$ 6.0 ), $0.5 \mathrm{M} \mathrm{NaCl}, 1 \mathrm{~mm} \mathrm{PMSF}$, and $1 \%$ Triton X-100. After 1 freezethaw, and sitting on ice for $1 \mathrm{hr}, 200 \mu \mathrm{l}$ buffer B [50 mM Na-acetate (pH, 6.0), $0.5 \mathrm{M} \mathrm{NaCl}, 1 \mathrm{~mm}$ PMSF, and $0.1 \%$ Triton X-100] was added to bring the total volume of the homogenate to $400 \mu \mathrm{l}$. This sample was centrifuged at $4^{\circ} \mathrm{C}$ for $5 \mathrm{~min}$ in a Beckman microfuge to remove the pellet of insoluble material, which was resuspended in $200 \mu \mathrm{l}$ buffer $\mathrm{B}$. To the resultant supernatant was added $100 \mu \mathrm{l}$ of a slurry of the affinity resin p-aminobenzoylarginine-Sepharose (a gift from Dr. T. H. Plummer, New York State Department of Health, Albany, NY) in buffer B. After rocking at $4^{\circ} \mathrm{C}$ for $45 \mathrm{~min}$, the p-aminobenzoylarginine-Sepharose was pelleted by centrifugation for $5 \mathrm{~min}$ in the microfuge. The resultant supernatant was taken as the unbound fraction. The p-aminobenzoylarginine-Sepharose was washed 3 times with $400 \mu \mathrm{l}$ buffer B, and proteins were eluted with $200 \mu \mathrm{l}$ of $0.5 \mathrm{M}$ arginine in buffer B. Bound proteins were collected by pelleting the p-aminobenzoylarginine-Sepharose and collecting the supernatant. Bound and unbound fractions were subjected to immunoblot analysis, and total CPH activity was determined in each fraction. The bound fraction was dialyzed against $20 \mathrm{~mm}$ Na-acetate $(\mathrm{pH}, 6.0)$ prior to measurement of $\mathrm{CPH}$ activity.

CNBr cleavage. Peptide maps, generated by cyanogen bromide (CNBr) 
cleavage (Gross, 1967), of the 55- and 65-kDa forms of CPH were compared. The SON and posterior pituitary dissected from 40 rats were each homogenized in $500 \mu l 25 \mathrm{~mm}$ Tris- $\mathrm{HCl}(\mathrm{pH}, 7.5)$. The 55- and $65-\mathrm{kDa}$ forms of $\mathrm{CPH}$ from each tissue homogenate was isolated by SDS-PAGE in tube gels $(5 \mathrm{~mm}$ diameter, $10 \mathrm{~cm}$ length). These $\mathrm{CPH}$ species were eluted from tube gel slices with an Isco electroeluter. Aliquots of isolated 55- and $65-\mathrm{kDa} \mathrm{CPH}$ were subjected to $\mathrm{CNBr}$ cleavage (Gross, 1967) by incubation at room temperature in $70 \%$ formic acid and $100 \mu \mathrm{g} / \mathrm{ml} \mathrm{CNBr}$ for $20 \mathrm{hr}$. These conditions have been commonly used for $\mathrm{CNBr}$ digestion of numerous proteins (Gross, 1967). Samples were lyophilized, and cleavage products were analyzed by $\mathrm{CPH}$ immunoblots on $14 \%$ SDS-PAGE gels.

\section{Results}

Carboxypeptidase $H$ in SON, ME-stalk, and posterior pituitary

The relative specific activities of $\mathrm{CPH}$ were assessed in rat $\mathrm{ME}-$ stalk (axon-enriched region) and posterior pituitary (nerve terminals) by determining the $\mathrm{CPH}$ activity:IR ratio in tissue homogenates (Fig. $2 a$ ). CPH activity was measured by following the conversion of ${ }^{3} \mathrm{H}$-benzoyl-Phe-Ala-Arg to ${ }^{3} \mathrm{H}$-benzoyl-PheAla (Stack et al., 1984), and CPH IR was measured by radioimmunoassay (Hook et al., 1985b). The CPH activity:IR ratio serves as an index of the level of catalytic activity per unit number of enzyme molecules and allows differentiation between highly active and inactive populations of $\mathrm{CPH}$. These ratios were $0.06 \pm 0.004$ and $0.30 \pm 0.01 \mathrm{pmol}( \pm \mathrm{SEM}){ }^{3} \mathrm{H}$-benzoylPhe-Ala/min.ng IR CPH in the ME-stalk and posterior pituitary, respectively, showing that $\mathrm{CPH}$ molecules in the posterior pituitary were 5 times more active than those in ME-stalk. In addition, CPH activities (pmol ${ }^{3} \mathrm{H}$-benzoyl-Phe-Ala $/ \mathrm{min} \cdot \mu \mathrm{g}$ protein) per total homogenate protein in the ME-stalk and posterior pituitary were 5 - and 33-fold greater, respectively, than that in the SON (Fig. 2b).

To confirm that CPH in nerve terminals of the posterior pituitary is axonally transported from neurons of the SON and PVN, CPH activity was determined in the posterior pituitary after stalk transection (Fig. 2c). At 13 days after stalk transection, when axons and nerve terminals are maximally degenerated (Laszlo and DeWied, 1966), CPH activity in the posterior pituitary was reduced to $8 \%$ of that in the sham-operated controls. Disappearance of $\mathrm{CPH}$ activity from the nerve terminals after transecting their axonal route indicates that the source of $\mathrm{CPH}$ in the posterior pituitary is from the magnocellular hypothalamic neurons.

These results (Fig. 2, $a-c$ ) suggest that $\mathrm{CPH}$ enzyme molecules may be activated during axonal transport from the SON to nerve terminals of the posterior pituitary.

\section{Multiple forms of $\mathrm{CPH}$}

The activation of $\mathrm{CPH}$ that we observed implies that inactive or partially active forms of the enzyme exist. To investigate these possibilities, the molecular forms of $\mathrm{CPH}$ present in tissue homogenates of the SON, ME-stalk, and posterior pituitary were analyzed by immunoblots with anti-CPH serum (Fig. $3 a$ ). Two CPH immunoreactive proteins of 65 and $55 \mathrm{kDa}$ (apparent molecular weight) were present in different amounts in each of these regions. The primary $\mathrm{CPH}$ species in the posterior pituitary was the $55-\mathrm{kDa}$ form, which corresponds to active $\mathrm{CPH}$ because it possesses the identical molecular weight as CPH purified from rat insulinoma (Davidson and Hutton, 1987). The ME-stalk and SON regions contained much higher levels of the $65-\mathrm{kDa}$ species. In the SON, a doublet of 67 and $65 \mathrm{kDa}$ was consistently observed.
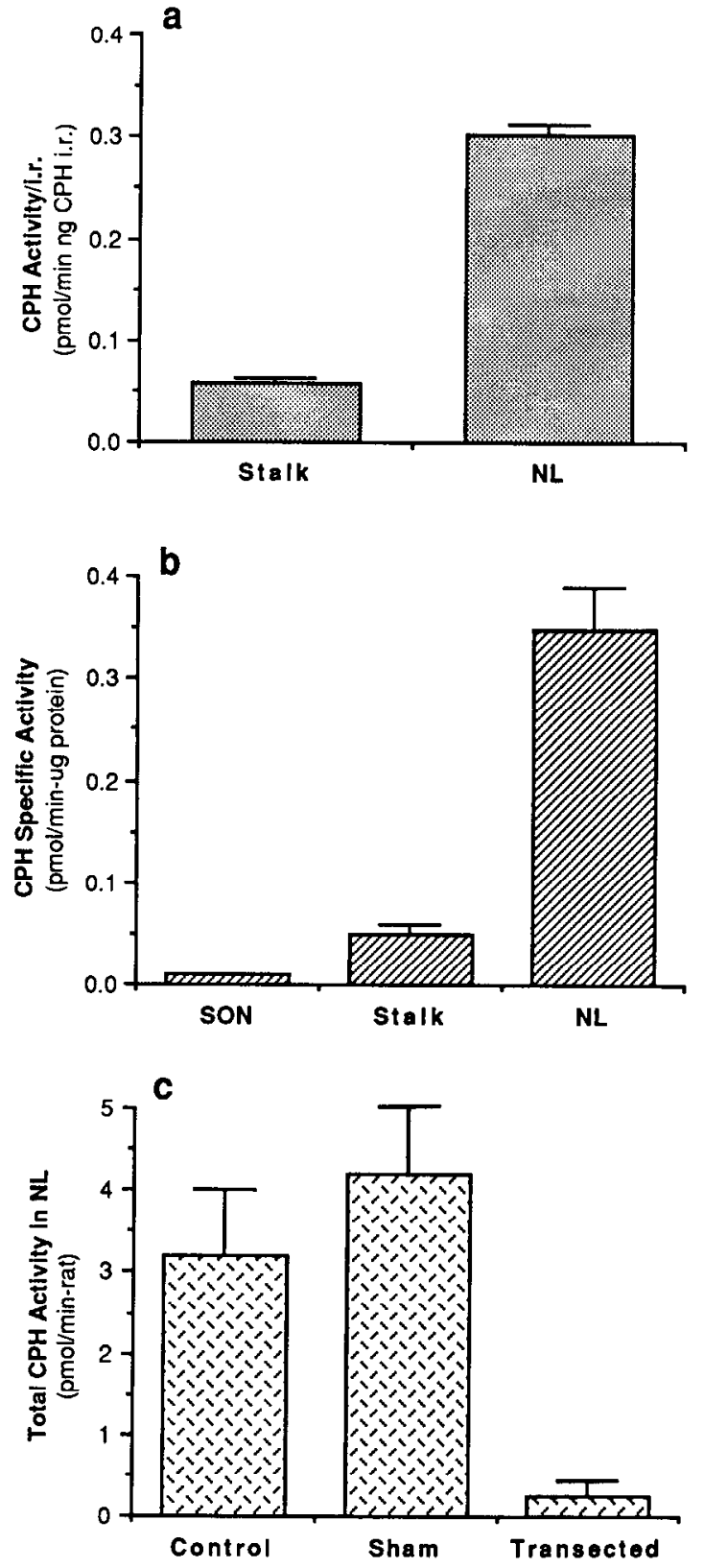

Figure 2. CPH in rat HNS. $a$, Ratio of CPH activity to immunoreactivity in the ME-stalk (Stalk) and ncural lobe $(N L) . n=3 ; p<$ 0.005 (statistically significant) by Student's $t$-test. $b$, CPH activity in the SON, ME-stalk, and neural lobe is expressed as pmol benzoyl-Phe-Ala/ $\min \cdot \mu \mathrm{g}$ protein for each region. $c$, Total $\mathrm{CPH}$ activity in the neural lobe after stalk transection. $n=3$ for control, and $n=2$ for sham and transected groups; $p<0.01$ (statistically significant compared to control or sham-operated controls) by Student's $t$-test. Vertical lines represent SEM.

The percentage of total CPH IR represented by the $55-\mathrm{kDa}$ species was $81 \%, 23 \%$, and $1 \%$, in the posterior pituitary, MEstalk, and SON, rcspcctively, as detcrmincd from the pcak arcas of densitometric scans of the immunoblots (Fig. $3 b$ ). The percentage of total immunoreactive $65-\mathrm{kDa}$ species in each region was $17 \%, 72 \%$, and $98 \%$ for the posterior pituitary, ME-stalk, and SON, respectively. Therefore, it appears that the SON contains almost exclusively the $65-\mathrm{kDa}$ form, while the ME-stalk contains a 3:1 ratio of 65- and 55-kDa species, and the posterior 
a

$\begin{array}{lll}\text { NL ST SON NL } & \text { ST } & \text { SON }\end{array}$

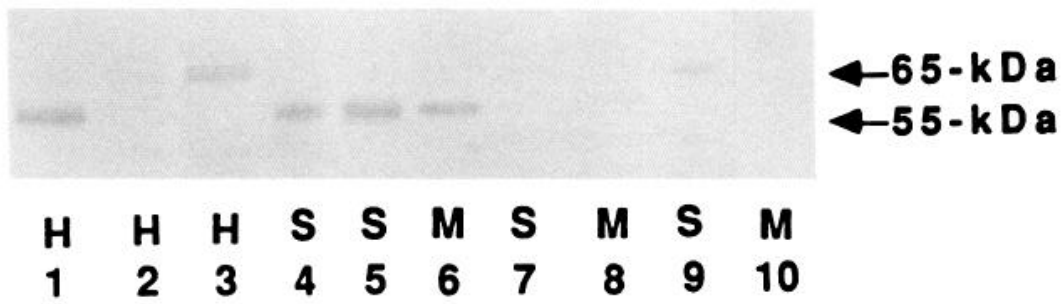

b

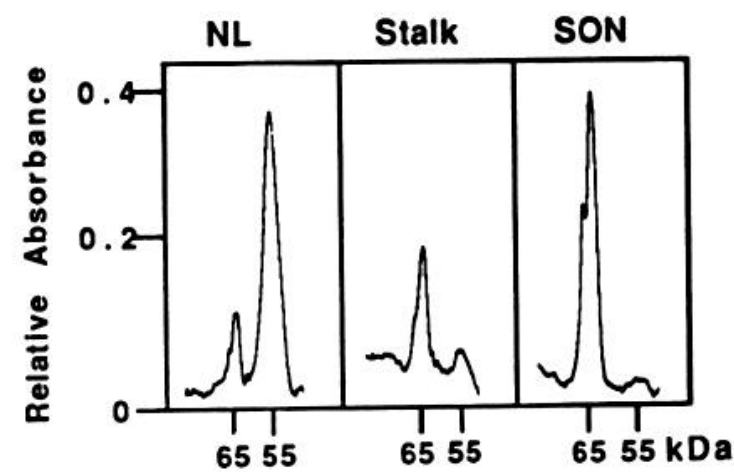

Figure 3. Immunoblot of $\mathrm{CPH}$ in rat HNS. $a$, Immunoblot of $\mathrm{CPH}$ in the $S O N$, Me-stalk $(S T)$, and neural lobe $(N L)$ tissue homogenates. For tissue homogenates $(H)$, relative amounts of tissue applied to each lane were as follows: lane 1 , neural lobe from 1 rat; lane 2 , ME-stalk from 2 rats; lane 3, SON from 1 rat. For soluble $(S)$ and membraneassociated $(M)$ fractions of homogenates, lanes $4,6,9$, and 10 represent tissue from 1 rat and lanes 5, 7, and 8 represent tissue from 2 rats. $b$, Relative levels of 65- and 55-kDa CPH in homogenates of SON, ME-stalk (Stalk), and neural lobe $(N L)$. Laser densitometric scans were taken of lanes 1, 2, and 3 of $a$. $c$, Immunoblot of CPH in the rat anterior (lane 1), intermediate (lane 2), and neural lobe (lane 4 ) pituitary homogenates.

C

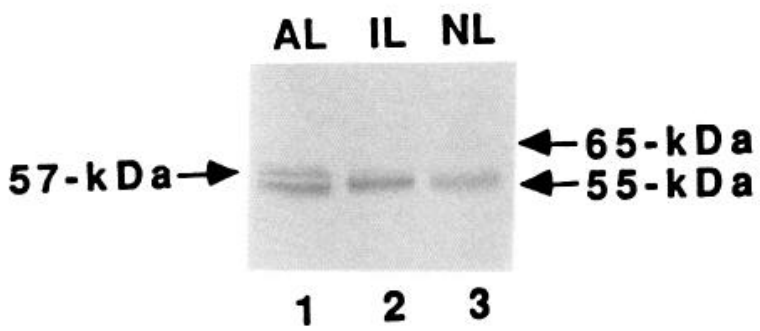

pituitary exhibits primarily the $55-\mathrm{kDa}$ species. $\mathrm{CPH}$ immunoblots of PVN (cell bodies) of the rat HNS were similar to the SON (data not shown).

Cell fractionation experiments (Fig. $3 a$ ) showed that the 65$\mathrm{kDa}$ form was primarily a soluble protein in the SON, while in the ME-stalk and posterior pituitary regions, it was associated with the membrane fraction. The $55-\mathrm{kDa}$ form in the posterior pituitary was present in soluble and membrane-associated fractions.

The relative distribution of the 65 - and $55-\mathrm{kDa}$ species in the rat anterior and intermediate pituitary was also examined on immunoblots (Fig. $3 \mathrm{c}$ ). The $55-\mathrm{kDa} \mathrm{CPH}$ found in the intermediate lobe appeared to be identical to that seen in neural lobe (posterior pituitary). However, the anterior lobe showed a doublet of 57- and 55-kDa apparent molecular weight. Almost no $65-\mathrm{kDa}$ species were found in the 3 lobes of the rat pituitary.

Analysis of the molecular forms of CPH in the bovine pituitary (Fig. 4) showed that substantial amounts of a $64-65-\mathrm{kDa}$ $\mathrm{CPH}$ exist in the anterior, intermediate, and neural lobes. The $64-65-\mathrm{kDa}$ species was present in greater amounts than the smaller, 55- and 52-kDa species. The anterior pituitary possessed both $55-$ and $52-\mathrm{kDa}$ forms that presumably correspond to the previously purified membrane (Supattapone et al., 1984) and soluble (Fricker and Snyder, 1983) forms of CPH, respectively. Intermediate and neural lobes contained the $52-\mathrm{kDa} \mathrm{CPH}$, but the $55-\mathrm{kDa}$ form was not detected.

\section{Analysis of active and inactive forms}

To determine whether the 65 - and/or 55-kDa species of $\mathrm{CPH}$ possess catalytic activity, the 2 forms from homogenates of rat SON, ME-stalk, and posterior pituitary were separated from one another by p-aminobenzoylarginine-Sepharose affinity chromatography (Fig. 5a), and their relative activities were measured. Immunoblots of the fractions show that the $65-\mathrm{kDa}$ form does not bind to the p-aminobenzoylarginine-Sepharose and that the $55-\mathrm{kDa}$ form binds and is eluted with arginine.

The unbound fraction, containing the $65-\mathrm{kDa}$ species, showed virtually no enzyme activity, whereas the bound fraction, containing the 55-kDa species, had almost all of the $\mathrm{CPH}$ activity present in each region (Fig. $5 b$ ). All enzyme activity in the 


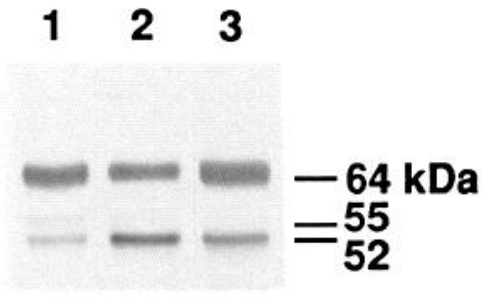

AL IL NL

Figure 4. Immunoblot of $\mathrm{CPH}$ in bovine pituitary. Homogenates of anterior (10 $\mu \mathrm{g}$ protein, lane 1$)$, intermediate ( $8 \mu \mathrm{g}$ protein, lane 2$)$, and neural lobes ( $8 \mu \mathrm{g}$ protein, lane 3 ) of the bovine pituitary was subjected to $\mathrm{CPH}$ immunoblot as described in Materials and Methods.

unbound fraction of the posterior pituitary was bound after a second passage through p-aminobenzoylarginine-Sepharose. The binding of the 55-kDa CPH to p-aminobenzoylarginine-Sepharose is consistent with purification of $55-\mathrm{kDa}$ rat $\mathrm{CPH}$ by this same affinity column (Davidson and Hutton, 1987). Purification of a single catalytically active, 55-kDa rat $\mathrm{CPH}$ (Davidson and Hutton, 1987) supports the proposal that the $65-\mathrm{kDa}$ immunoreactive $\mathrm{CPH}$ is an inactive form of $\mathrm{CPH}$.

Kinetic properties of the $55-\mathrm{kDa} \mathrm{CPH}$ from the SON, MEstalk, and posterior pituitary were compared using enzyme isolated by affinity chromatography and, therefore, free from the $65-\mathrm{kDa}$ form. The apparent $K_{\mathrm{m}}$ values (determined on Lineweaver-Burk plots) for the 55-kDa CPH in the SON, ME-stalk, and posterior pituitary were $1.2,1.0$, and $1.2 \mu \mathrm{M}$ benzoyl-PheAla-Arg, respectively. In the presence of $1 \mathrm{~mm} \mathrm{CoCl}, \mathrm{CPH}$ activities in the SON, ME-stalk, and posterior pituitary were stimulated 2-fold. The similar $K_{\mathrm{m}}$ values and similar degree of elevation of activity by $\mathrm{CoCl}_{2}$ for the enzyme in the SON, MEstalk, and posterior pituitary demonstrates that the $55-\mathrm{kDa}$ form of $\mathrm{CPH}$ is the same in each of the 3 regions.

The levels of total enzyme activity were compared with the amounts of the 65 - or $55-\mathrm{kDa}$ forms in the 3 regions (Fig. 6). Total CPH activity and levels of the $55-\mathrm{kDa} \mathrm{CPH}$ had a correlation coefficient of 0.997 . However, levels of enzyme activity and levels of the $65-\mathrm{kDa}$ form of $\mathrm{CPH}$ had a correlation coefficient of -0.964 . As vesicles are transported from the SON to nerve terminals of the posterior pituitary, the decrease in levels of inactive, $65-\mathrm{kDa} \mathrm{CPH}$ and the concurrent increase in relative levels of activity and active, $55-\mathrm{kDa} \mathrm{CPH}$ support the hypothesis that the $65-\mathrm{kDa}$ form is converted to active, $55-\mathrm{kDa} \mathrm{CPH}$ during axonal transport in the rat HNS.

\section{Peptide maps of the 65- and 55-kDa forms of $\mathrm{CPH}$}

Peptide maps of the 65- and 55-kDa forms of CPH were compared to provide further evidence for a precursor-product relationship between these $\mathrm{CPH}$ proteins. Peptide fragments generated by $\mathrm{CNBr}$ cleavage were analyzed by $\mathrm{CPH}$ immunoblots (Fig. 7). Characterization of the $\mathrm{CPH}$ antibody demonstrated that this polyclonal antibody recognizes multiple epitopes, because proteolysis of purified bovine $\mathrm{CPH}$ by $S$. aureus V8 protease produced fragments of $46,38,30,27,20$, and $15 \mathrm{kDa}$ that were all recognized by the $\mathrm{CPH}$ antiserum in immunoblots (data not shown). $\mathrm{CNBr}$ treatment, which selectively attacks methionine residues within proteins to result in cleavage of methionyl peptide bonds (Gross, 1967), resulted in the formation of 4- and 3 -peptide fragments from the $65-$ and $55-\mathrm{kDa} \mathrm{CPH}$ species,

\section{a}
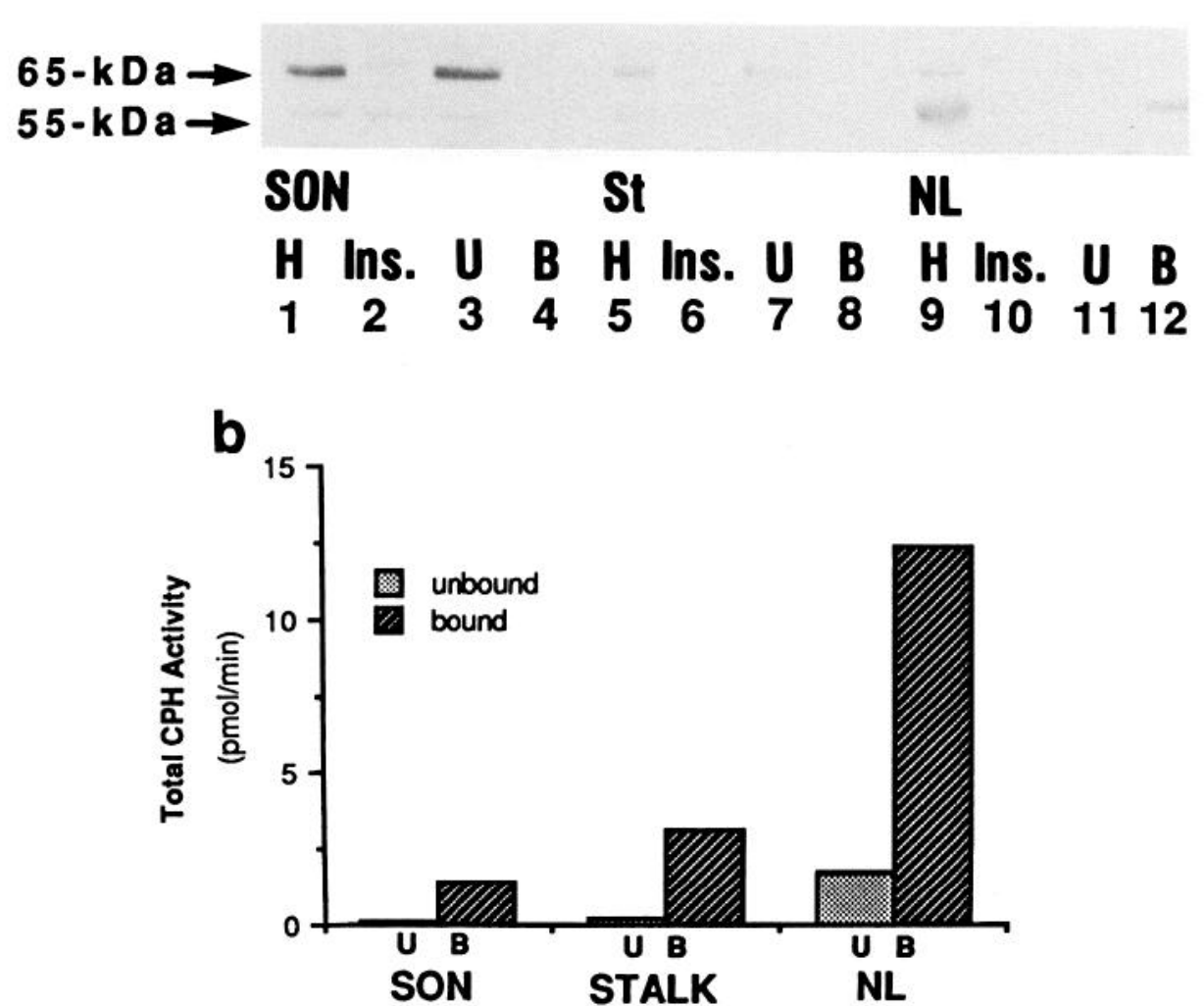

Figure 5. p-Aminobenzoylarginine affinity chromatography of $65-\mathrm{kDa}$ and 55-kDa CPH. $a$, Immunoblot of $\mathrm{CPH}$ in homogenate $(H)$, triton-insoluble (Ins.) and p-aminobenzoylarginine-Sepharose unbound $(U)$ and bound $(B)$ fractions of SON, ME-stalk $(S T)$, and neural lobe $(N L)$. The amounts of homogenate, insoluble, and unbound fractions applied to the gel lanes represent tissue from 1.5 rats; bound fractions represent 2 rats. $b$, Total $\mathrm{CPH}$ activity (from 20 rats) in unbound $(U)$ and bound $(B)$ fractions from the $S O N$, MEstalk (Stalk) and neural lobe $(N L)$. 


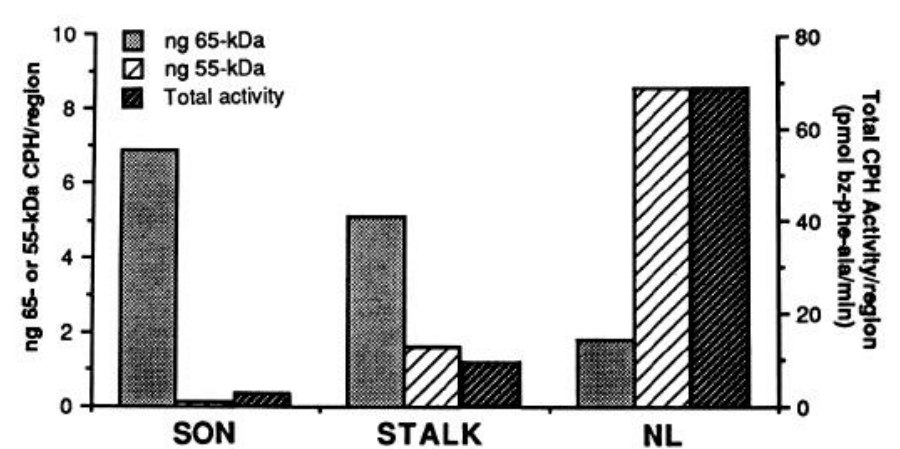

Figure 6. Correlation of activity with $55-\mathrm{kDa}$ or $65-\mathrm{kDa}$ forms of $\mathrm{CPH}$ in SON, ME-stalk, and neural lobe. Total CPH activity (dark bars), ng immunoreactive 65-kDa CPH (gray bars), and ng immunoreactive 55$\mathrm{kDa} \mathrm{CPH}$ (light bars) were measured and calculated for each rat. Total CPH IR represents both the $65-$ and $55-\mathrm{kDa}$ forms. The amounts of immunoreactive $65-\mathrm{kDa}$ and $55-\mathrm{kDa} \mathrm{CPH}$ were calculated from peak areas of densitometric scans of CPH immunoblots (shown in Fig. 3a,b) in combination with RIA measurement of total CPH immunoreactivity for each region. The correlation coefficient for $\mathrm{CPH}$ activity and levels of $55-\mathrm{kDa} \mathrm{CPH}$ was 0.997 ; for $65-\mathrm{kDa} \mathrm{CPH},-0.964$.

respectively, as detected by $\mathrm{CPH}$ immunoblots. If the 65- and 55-kDa species are related, a greater number of fragments should be generated from the $65-\mathrm{kDa}$ than from the $55-\mathrm{kDa}$ form; this finding was observed. $\mathrm{CNBr}$ treatment resulted in 2 bands at 35.5 and $29.0 \mathrm{kDa}$ that were common to peptide maps of both the $65-$ and $55-\mathrm{kDa} \mathrm{CPH}$ proteins. These similar peptide fragments support the hypothesis that the $65-$ and $55-\mathrm{kDa}$ proteins appear to be structurally related.

\section{Discussion}

Peptide hormones are synthesized as large precursors that require the action of endopeptidases and $\mathrm{CPH}$ to generate the smaller, biologically active peptides. Little is known, however, about the regulation of these protease activities during prohormone processing. In this study, we have examined the molecular forms of $\mathrm{CPH}$ in the rat HNS, which allows biochemical analysis of anatomically distinct regions containing predominantly cellbody, axon, and nerve-terminal regions of a defined population of peptidergic neurons. We demonstrate that the SON, a cellbody-enriched region, possesses an inactive, $65-\mathrm{kDa} \mathrm{CPH} z y-$ mogen that is presumably processed during axonal transport to the active $55-\mathrm{kDa} \mathrm{CPH}$, the major form present in nerve terminals of the posterior pituitary.

The predominant form of $\mathrm{CPH}$ in the SON was found to be a $65-\mathrm{kDa}$ species of $\mathrm{CPH}$. A minor $67-\mathrm{kDa}$ form of $\mathrm{CPH}$ in the SON may represent prepro-CPH or an intermediate in the processing of prepro- $\mathrm{CPH}$. The cDNA for rat prepro- $\mathrm{CPH}$ predicts a molecular weight of 53,315 $\mathrm{Da}$ for this precursor; therefore, the larger $67-$ and $65-\mathrm{kDa}$ forms detected in the SON probably represent pro- $\mathrm{CPH}$ that has undergone posttranslational modifications, such as glycosylation. The major $65-\mathrm{kDa}$ $\mathrm{CPH}$ intermediate in the SON represented $98 \%$ of the total CPH IR, whereas the active, $55-\mathrm{kDa}$ form represented only $2 \%$ of the total CPH IR in this region. The $65-\mathrm{kDa} \mathrm{CPH}$ is inactive and does not bind to p-aminobenzoylarginine-Sepharose.

The $65-\mathrm{kDa} \mathrm{CPH}$ appears to be processed during axonal transport, as demonstrated by the presence of both $65-$ and $55-\mathrm{kDa}$ forms of $\mathrm{CPH}$ in the ME-stalk, which contains primarily axons. Processing during axonal transport results in the presence of
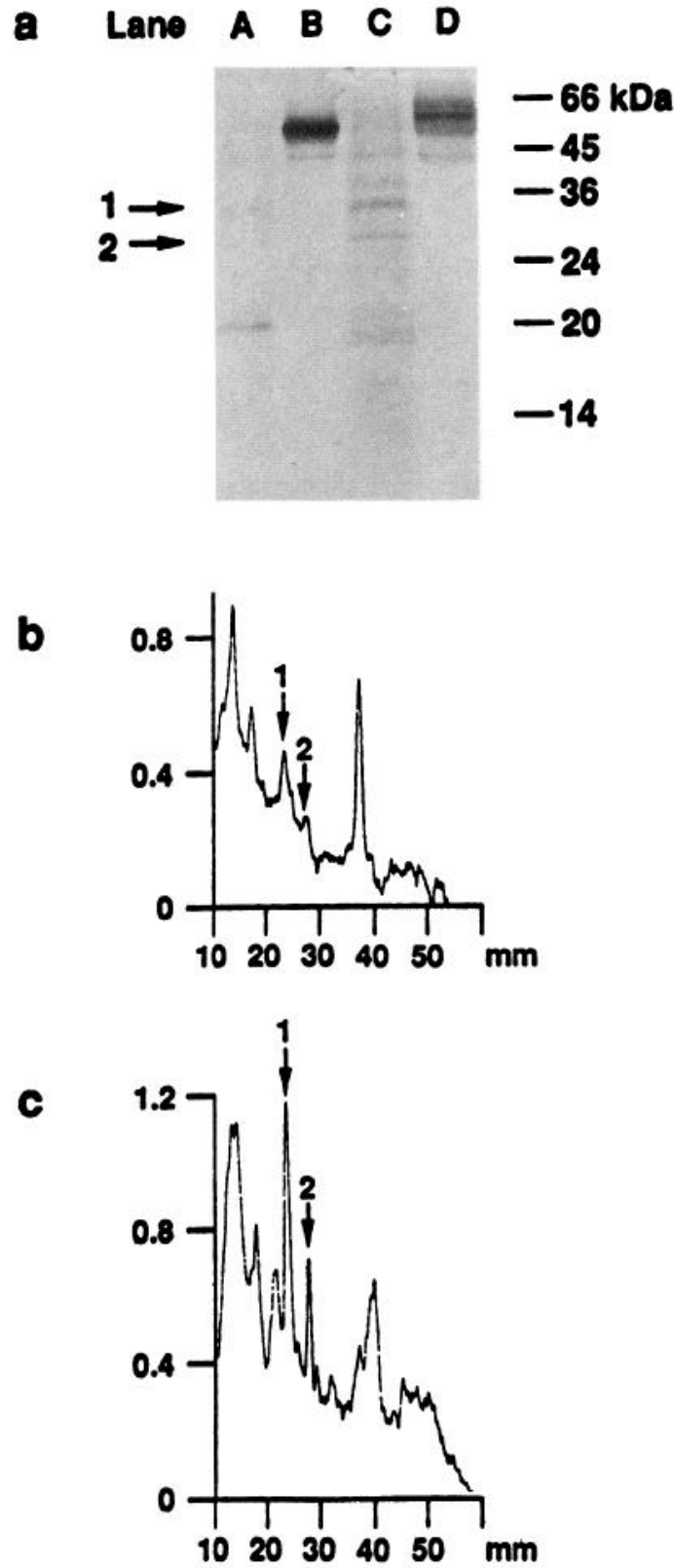

Figure 7. Peptide maps of $65-$ and $55-\mathrm{kDa}$ forms of $\mathrm{CPH}$. The $65-$ and $55-\mathrm{kDa}$ forms were isolated from the SON and posterior pituitary (described in Materials and Methods) and subjected to CNBr cleavage. The resultant peptide fragments were separated on $14 \%$ SDS-PAGE gels and transferred to nitrocellulose membranes for $\mathrm{CPH}$ immunoblots shown in a: lane $A, 55-\mathrm{kDa} C P H, C N B r-t r e a t e d ; B, 55-\mathrm{kDa} C P H$, untreated; $C, 65-\mathrm{kDa} C P H, \mathrm{CNBr}$-treated; and $D, 65-\mathrm{kDa} C P H$, untreated. Peptide fragments 1 and 2 ( 35.5 and $29.0 \mathrm{kDa}$, respectively) were common to peptide maps of both the $55-$ and $65-\mathrm{kDa} C P H$ species. $b$ and $c$ show densitometric scans of lanes $A$ and $C$ (from $a$ ), respectively; these scans confirm the identical electrophoretic mobilities of peptides 1 and 2.

active $55-\mathrm{kDa} \mathrm{CPH}$ as the major form ( $80 \%$ of total CPH IR) present in nerve terminals of the posterior pituitary. The 55$\mathrm{kDa}$ form of $\mathrm{CPH}$ binds to p-aminobenzoylarginine-Sepharose, an affinity resin used in purifications of $\mathrm{CPH}$. The correlation between $\mathrm{CPH}$ activity and levels of $55-\mathrm{kDa} \mathrm{CPH}$, and the inverse correlation between $\mathrm{CPH}$ activity and levels of $65-\mathrm{kDa}$ $\mathrm{CPH}$ in cell bodies, axons, and nerve-terminal regions of the 
HNS support the hypothesis that the $65-\mathrm{kDa}$ protein appears to be converted to mature $55-\mathrm{kDa} \mathrm{CPH}$ during axonal transport.

The presence of some peptidergic inputs terminating in the SON and ME-stalk should be considered in the interpretation of our data implicating processing of pro-CPH during axonal transport. In the rat SON, previous immunohistochemical studies (Hook et al., 1985b) show that CPH is localized to the cytoplasm and is absent in nuclei of the neuronal perikarya. If the observed CPH IR was from peptidergic inputs terminating on SON neurons, the nuclear area of the cells would show immunostaining, representing terminals on plasma membranes above the nuclei. However, the lack of nuclear and presence of cytoplasmic immunostaining indicates that the majority of 65 $\mathrm{kDa} \mathrm{CPH}$ in the SON is probably localized to cell bodies. In nerve terminals of the posterior pituitary, the $55-\mathrm{kDa} \mathrm{CPH}$ was predominant compared to the $65-\mathrm{kDa}$ form; this finding may be representative of many neurons, suggesting that peptidergic terminals in the SON may contain small amounts of $55-\mathrm{kDa}$ $\mathrm{CPH}$ detected in this region. In addition, in the ME-stalk, the presence of some peptidergic nerve terminals in this region may contribute to the content of $55-\mathrm{kDa} \mathrm{CPH}$; therefore, the $65-$ $\mathrm{kDa}: 55-\mathrm{kDa} \mathrm{CPH}$ ratio within axons of the ME-stalk may be higher than observed in homogenates of this region. Further investigation of the subcellular localization will require electron microscopic immunohistochemical studies with proCPH- and CPH-specific antibodies.

Peptide maps of the 65- and 55-kDa forms of CPH provided further evidence for a precursor-product relationship between these 2 proteins. After cleavage by $\mathrm{CNBr}$ at methionyl peptide bonds, 2 species of 29.0 and $35.5 \mathrm{kDa}$ were common to peptide maps of both the 65- and 55-kDa forms of $\mathrm{CPH}$. The apparent $M_{r}$ values of the peptide fragments generated from the 65- and $55-\mathrm{kDa}$ proteins are consistent with predicted molecular weights of $\mathrm{CNBr}$-cleavage products resulting from the partial digestion of precursor and mature forms of $\mathrm{CPH}$, as described below.

Based on the amino acid sequence of rat $\mathrm{CPH}$ deduced from its cDNA (Fricker et al., 1989; Rodriguez et al., 1989), production of the $29.0-\mathrm{kDa} \mathrm{CNBr}$ fragment would be consistent with cleavage of the 55-kDa CPH (residue 1-434, numbered according to Rodriguez et al., 1989) at Met-250 to result in a fragment of $1-250$ with a calculated $M_{\mathrm{r}}$ of $28,134 \mathrm{Da}$ (unglycosylated). Cleavage of the $65-\mathrm{kDa}$ at Met-(-6) and Met-250 would generate a fragment with an $M_{r}$ of $28,904 \mathrm{Da}$ (calculated without glycosylation), which would not differ in apparent electrophoretic mobility (on SDS-PAGE) from the 28,134-Da fragment generated from $55-\mathrm{kDa}$ CPH. Bccause it is known that $55-\mathrm{kDa}$ CPH is glycosylated (Davidson and Hutton, 1987), glycosylation of these fragments at Asn-97 could increase their apparent $M_{r}$ to $29.0 \mathrm{kDa}$.

Production of the $35.5-\mathrm{kDa}$ fragment would be consistent with cleavage of $55-\mathrm{kDa} \mathrm{CPH}$ at Met-284 to generate fragment 1-284 of 31,717 Da and would also be consistent with cleavage at Met-1 12 and Met-422 to produce fragment 113-422 of 34,090 Da. Similarly, cleavage of $65-\mathrm{kDa} \mathrm{CPH}$ at Met-(-6) and Met284 or at Met-112 and Met-422 would generate fragments of 32,487 and $34,090 \mathrm{Da}$, respectively. These calculated $M_{r}$ values are for unglycosylated fragments. Glycosylation at Asn-97 or Asn-348 could increase the sizes of these fragments to $35.5 \mathrm{kDa}$. While mature rat CPH of $55 \mathrm{kDa}$ is deglycosylated to $50 \mathrm{kDa}$ (Davidson and Hutton, 1987), the degree of glycosylation at each Asn-97 or Asn-348 site is unknown.
Most of the inactive, 65-kDa CPH in the SON was present as a soluble protein, yet in the ME-stalk, it was primarily a membrane-associated protein. As the $\mathrm{CPH}$ precursor is routed through the rough endoplasmic reticulum and Golgi apparatus, it may be located within the soluble compartments of these organelles, and when it is packaged into secretory vesicles, it may be associated with the vesicle membrane. The 55-kDa form of $\mathrm{CPH}$ in the posterior pituitary appears to be soluble and membrane associated.

It is now apparent that previous immunocytochemical studies of CPH localization in the rat SON and PVN (Hook et al., $1985 \mathrm{~b}$ ) detected the presence of both the inactive $65-\mathrm{kDa}$ and active 55-kDa species of CPH. Another study (Chesselet and Hook, 1988) of CPH localization by immunocytochemistry most likely represents detection of both $65-$ and $55-\mathrm{kDa}$ species. It is not known, however, if the visualization of CPH in the SON and PVN by in vitro autoradiography with ${ }^{3} \mathrm{H}$-GFMSA (I ynch et al., 1984, 1986), a potent, active site-directed inhibitor of CPH (McKay and Plummer, 1978), represents labeling of the 65 - in addition to the $55-\mathrm{kDa}$ form of $\mathrm{CPH}$. Since in vitro autoradiography detects primarily membrane-bound components because of the washing procedure that results in removal of soluble proteins and since the $65-\mathrm{kDa} \mathrm{CPH}$ species in this study was present in a soluble fraction of the SON homogenate, it is likely that ${ }^{3} \mathrm{H}$-GEMSA autoradiography of $\mathrm{CPH}$ in cellbody-enriched areas of the SON and PVN preferentially detected the 55-kDa CPH.

The results of this study suggest that the extent of zymogen conversion to active $\mathrm{CPH}$ could vary from tissue to tissue. Evidence for tissue differences in the relative amounts of the molecular forms of $\mathrm{CPH}$ was demonstrated in the rat and bovine pituitary. The 55-kDa form of $\mathrm{CPH}$ was the major form present in the rat anterior and intermediate pituitary. The rat anterior lobe also showed a $57-\mathrm{kDa}$ form that was not present in intermediate or posterior lobes. The $65-\mathrm{kDa}$ form of $\mathrm{CPH}$ was virtually absent in the 3 lobes of the rat pituitary, whereas it was the major species present in the SON.

In contrast to the rat, the 3 lobes of the bovine pituitary showed substantial amounts of a $64-65-\mathrm{kDa}$ form of $\mathrm{CPH}$ that was present in higher quantities than the smaller, 55- and 52$\mathrm{kDa}$ forms of $\mathrm{CPH}$. The 55- and 52-kDa forms detected in this study appear to correspond to the previously described (Fricker and Snyder, 1983; Supattapone et al., 1984) membrane (apparent $M_{r}, 52.5 \mathrm{kDa}$ ) and soluble (apparent $M_{r}, 50.0 \mathrm{kDa}$ ) forms of bovine CPH, respectively. The small differences in apparent $M_{\text {r }}$ of bovine CPH (55 and $52 \mathrm{kDa}$ ) detected in this study comparcd to reportcd purificd $\mathrm{CPH}(52.5$ and $50 \mathrm{kDa})$ can be duc to our observation that the apparent molecular weights of proteins on SDS-PAGE can vary by $2-5 \mathrm{kDa}$ from gel to gel. The anterior lobe contained both the $55-$ and $52-\mathrm{kDa}$ forms of $\mathrm{CPH}$. The intermediate and neural lobes possessed the $52-\mathrm{kDa}$ form but not the $55-\mathrm{kDa}$ form. These results suggest that the processing of pro- $\mathrm{CPH}$ is tissue specific.

Tissue-specific processing of pro-CPH implies that the relative levels of peptides extended at the $\mathrm{COOH}$ terminus with basic amino acid residues may vary from one cell to another. Evidence for differences in the extent of prohormone processing at the carboxypeptidase step has been shown (Altstein and Gainer, 1988) in developmental studies of prooxytocin and provasopressin processing in the rat HNS. After removal of the $\mathrm{COOH}-$ terminal basic residues by $\mathrm{CPH}$, the products oxytocin-Gly and vasopressin-Gly undergo $\mathrm{COOH}$-terminal amidation to form 
the final physiologically active hormoncs. At onc stagc of cmbryogenesis, oxytocin-Gly ${ }^{10}$ Lys $^{11} \mathrm{Arg}^{12}$ was detected, but the completely processed (amidated) form was absent; however, fully processed vasopressin was present. Oxytocin and vasopressin precursors are synthesized in separate neurons. These studies show that there may be a block at the step of CPH processing in oxytocin cells but not in vasopressin cells. Whether or not this block may be due to incomplete processing of the $\mathrm{CPH}$ zymogen itself is unknown and requires further study.

What mechanism might control the conversion of the $\mathrm{CPH}$ zymogen to catalytically active $\mathrm{CPH}$ ? Amino acid sequence analysis of the rat CPH cDNA shows that the $\mathrm{COOH}$ terminus of the prosegment within pro-CPH contains 5 arginine residues adjacent to the $\mathrm{NH}_{2}$ terminus of CPH (Fricker et al., 1989; Rodriguez et al., 1989). These multiple basic residues are present at the $\mathrm{COOH}$ terminus of many prosegments within propeptides (Eipper et al., 1987; Furie and Furie, 1988) and are indicative of processing by endoproteolytic enzymes. Therefore, the hypothesis that a protease converts pro-CPH to the $55-\mathrm{kDa}$ form suggests that zymogen activation could be an additional level of regulation in peptide hormone biosynthesis. It will be important to understand how the activities of multiple processing enzymes are coordinately regulated to result in complete prohormone processing.

\section{References}

Altstein M, Gainer H (1988) Differential biosynthesis and posttranslational processing of vasopressin and oxytocin in rat brain during embryonic and postnatal development. J Neurosci 8:3967-3977.

Brownstein MJ, Russell JT, Gainer H (1980) Synthesis, transport, and release of posterior pituitary hormones. Science 207:373-378.

Chesselet M-F, Hook VYH (1988) Carboxypeptidase H-like immunoreactivity in the striatum of cats and monkeys. Reg Peptides 20: 151-159.

Davidson HW, Hutton JC (1987) The insulin-secretory-granule carboxypeptidase $\mathrm{H}$, purification and demonstration of involvement in proinsulin processing. Biochem J 245:575-582.

Docherty K, Steiner D (1982) Posttranslational proteolysis in polypeptide hormone biosynthesis. Ann Rev Physiol 44:626-638.

Eipper BA, Park LP, Dickerson IM, Keutmann HT, Thiele EA, Rodriguez H, Schofield PR, Mains RE (1987) Structure of the precursor to an enzyme mediating $\mathrm{COOH}$-terminal amidation in peptide biosynthesis. Mol Endocrinol 1:777-790.

Fricker LD, Snyder SH (1982) Enkephalin convertase: purification and characterization of a specific enkephalin-synthcsizing carboxypeptidase localized to adrenal chromaffin granules. Proc Natl Acad Sci USA 79:3886-3890.

Fricker LD, Snyder SH (1983) Purification and characterization of enkephalin convertase, an enkephalin-synthesizing carboxypeptidase. J Biol Chem 258:10950-10955.

Fricker LD, Adelman JP, Douglass J, Thompson RC, von Strandmann RP, Hutton J (1989) Isolation and sequence analysis of cDNA for rat carboxypeptidase E (EC 3.4.17.10), a neuropeptide processing enzyme. Mol Endocrinol 3:666-673.

Furie B, Furie BC (1988) The molecular basis of blood coagulation. Cell 53:505-518.
Gainer H, Sarne Y, Brownstein MJ (1977) Biosynthcsis and axonal transport of rat neurohypophysial proteins and peptides. J Cell Biol 73:366-381.

Gainer H, Russell JT, Loh YP (1985) The enzymology and intracellular organization of peptide precursor processing: the secretory vesicle hypothesis. Prog Neuroendocrinol 40:171-184.

Gross E (1967) The cyanogen bromide reaction. Methods Enzymol 11:238-255.

Hook VYH, Eiden LE (1985) Nicotine stimulates release of carboxypeptidase peptide hormone processing enzyme and (met)enkephalin from cultured chromaffin cells. Biochem Biophys Res Comm 128: 563-570.

Hook VYH, LaGamma EF (1987) Feedback inhibition of carboxypeptidase H. J Biol Chem 262:12583-12588.

Hook VYH, Loh PY (1984) Carboxypeptidase B-like converting enzyme activity in secretory granules of rat pituitary. Proc Natl Acad Sci USA 81:2776-2780.

Hook VYH, Eiden LE, Brownstein MJ (1982) A carboxypeptidase processing enzyme for enkephalin precursors. Nature 295:341-342.

Hook VHY, Eiden LE, Pruss RM (1985a) Selective regulation of carboxypeptidase peptide hormone processing enzyme during enkephalin biosynthesis in cultured bovine adrenomedullary chromaffin cells. J Biol Chem 260:5991-5997.

Hook VYH, Mezey E, Fricker LD, Pruss RM, Siegel RE, Brownstein MJ (1985b) Immunochemical characterization of carboxypeptidase B-like peptide hormone processing enzyme. Proc Natl Acad Sci USA 82:4745-4749.

Kanmera T, Chaiken IM (1985) Pituitary enzyme conversion of putative synthetic oxytocin precursor intermediates. J Biol Chem 260: 10118-10124.

Laszlo SA, DeWied D (1966) Pituitary-adrenal system in rats bearing lesions in the pituitary stalk. Endocrinol 79:547-553.

Liston D, Patey G, Rossier J, Verbanck P, Vanderhaeghen JJ (1984) Processing of proenkephalin is tissue-specific. Science 225:734-737.

Lowry OH, Rosebrough NJ, Farr AL, Randall RJ (1951) Protein measurement with the folin phenol reagent. J Biol Chem 193:265275.

Lynch DR, Strittmatter SM, Snyder SH (1984) Enkephalin convertase localization by ${ }^{3} \mathrm{H}$-guanidinoethylmercaptosuccinic acid autoradiography: selective association with enkephalin-containing neurons. Proc Natl Acad Sci USA 81:6543-6547.

Lynch DR, Strittmatter SM, Vanable JC, Snyder SH (1986) Enkephalin convertase: localization to specific neuronal pathways. J Neurosci 6:1662-1675.

McKay TJ, Plummer TH (1978) By-product analogues for bovine carboxypeptidase B. Biochemistry 17:401-405.

Rodriguez C, Brayton KA, Brownstein M, Dixon JE (1989) Rat preprocarboxypeptidase $H$, cloning, characterization, and sequence of the cDNA and regulation of the mRNA by corticotropin-releasing factor. J Biol Chem 264:5988-5995.

Stack G, Fricker LD, Snyder SII (1984) A sensitive radiometric assay for enkephalin convertase and other carboxypeptidase B-like enzymes. Life Sci 34:113-121.

Supattapone S, Fricker LD, Snyder SH (1984) Purification and characterization of a membrane-bound enkephalin-forming carboxypeptidase, "enkephalin convertase." J Neurochem 42:1017-1023.

Walter P, Gilmore R, Blobel G (1984) Protein translocation across the endoplasmic reticulum. Cell 38:5-8.

Webb EC (1986) Nomenclature committee of the international union of biochemistry (NC-IUB), enzyme nomenclature recommendations 1984. Eur J Biochem 157:16. 